\title{
ORIGINAL ARTICLE \\ Transcendence, fast and slow: Infinite Jest and the dynamics of a cultural splash
}

\section{Thomas Medvetz ${ }^{1}$}

Accepted: 22 September 2021 / Published online: 19 January 2022

(c) The Author(s) 2022

\begin{abstract}
This paper builds on two leading models of artistic practice, the "network-building" and "autonomous sphere" approaches, to show how an expressive work can reverse the normal antinomy between artistic recognition and commercial success and become an immediate crossover hit. Focusing on a single "pointy" case from the world of literature - the 1996 novel Infinite Jest, by David Foster Wallace-I ask whether a set of unique social dynamics attends the process of making a "cultural splash." In the case of Infinite Jest, success came from occupying an intermediate position in the "space between fields" and eliciting a complex, mutually referential response from cultural intermediaries. In this way, the book attracted samplings of recognition and renown, the contrasting reputational ingredients associated with an enduring cultural appeal. Nevertheless, the novel's declining reputation in recent years suggests that we should differentiate a cultural splash from the better-known dynamics of canonization and classicization. In the paper's final section, I conceptualize a cultural splash as an effect generated by works that undergo a "fast transcendence" by unmooring themselves temporarily from the limiting effects of being counted as "art" or "pop."
\end{abstract}

Keywords Literature $\cdot$ Novels $\cdot$ Art $\cdot$ Expressive works $\cdot$ Transcendence $\cdot$ Cultural intermediaries

\section{Introduction ${ }^{1}$}

Two complementary lines of research and theorizing in the sociology of culture establish a framework for thinking about how successful novels, films, plays, musical recordings, paintings, sculptures, monuments, and other expressive works

\footnotetext{
1 The idea of a cultural splash was suggested to me by Philip Smith. I am indebted to him not only for this indispensable suggestion, but also for his incisive feedback on an earlier draft.
}

Thomas Medvetz

tmedvetz@ucsd.edu

1 Department of Sociology, University of California, San Diego, La Jolla, CA, USA 
capture people's attention and, in the best-case scenarios, become lasting points of cultural reference. The first is a collection of studies reaching back to Lang and Lang's (1988) influential theory of the "survival of reputation," which pinpoints recognition plus renown as the basic formula for an enduring legacy. To survive over time, these studies suggest, an expressive work must establish a crossover appeal by attracting two distinct forms of validation: first, "the esteem [of] others in the... 'art world" from which it came, and second, general notoriety or "recognition beyond the esoteric circles in which the artist moves" (ibid., 84; see also, Lang and Lang 1990). It is through the combination of these ingredients, the theory suggests, that a work builds its legacy. Meanwhile, a second body of research sharpens this point by spotlighting the inherent difficulty of this task. This is the key implication of Bourdieu's $(1980,1984,1993)$ theory of the "market for symbolic goods," which depicts general and specific forms of recognition as rooted in antithetical principles. Bourdieu's point is that the tastes of high-cultural specialists are not merely distinct from, but form largely in opposition to, those of general audiences. Thus, what is considered cutting edge in the world of artists is seldom popular, and vice versa, what is popular is rarely taken seriously by artists and aficionados.

A valuable link between these two literatures can be found in Santana-Acuña's (2014) study of literary classicization. This is the notion of transcendence, which serves first to clarify the mechanism behind Lang and Lang's theory: What is so special about the combination of recognition and renown? Santana-Acuña's answer is that, when merged, the two ingredients can have a synergistic effect, since each type of validation may counteract the limitations of the other. More specifically, while the imprimatur of art can shield a work from trivializing labels like pop, general renown can liberate its meaning from the control of critics, art historians, and other specialists. The result is a "best of both worlds" scenario in which the expressive work seems to "transcend" the opposition between high and low culture, acquiring both a patina of sacredness and a broad social reach and relevance. This description adds substance to Lang and Lang's formula, but it also upholds Bourdieu's point about the inherent difficulty of combining general and specific forms of recognition. In the case study on which Santana-Acuña's theory is based-which focuses on Gabriel García Márquez's novel One Hundred Years of Solitude-the picture of transcendence that emerges is that of a slow, painstaking process. Or, more accurately, a conjunction of processes: Although García Márquez's book was lauded by critics upon its release in 1967, it was long pigeonholed as a work of Third World or Latin American literature. As Santana-Acuña shows, only when audiences with no stake in its literary standing per se discovered the book and, years later, began to assign it new meanings did One Hundred Years of Solitude become a bona fide classic (see also Santana-Acuña 2020).

Here, then, is the double-sided prediction that forms the backdrop for much of the current sociological thinking about how expressive works attract cultural recognition: On the one hand, since cultural specialists and general audiences rarely converge in their appreciations of specific works, we should not expect a work that appeals to critics and aficionados to succeed on the mass market, or vice versa. On the other hand, the works with the greatest staying power are those that manage to overcome the art/commerce antinomy and develop a crossover appeal. The notion 
of transcendence bridges the two points: Whenever artistic consecration and general notoriety are combined-usually as successively formed layers in an artist's or work's reputation ${ }^{2}$ - the result is a kind of charismatic or enchanted quality.

As robust as this framework is, however, it is also highly general. Accordingly, much of the research it has inspired has been concerned with probing its limits, clarifying its ambiguities, and determining its exact reach (e.g., Benzecry 2011; Childress 2017). It is in this spirit that I pose the central question for this paper: What should we do with the rare but memorable cases of expressive works that defy the usual pattern by making an immediate "cultural splash"? Shadings of this phenomenon can be seen in recent sensations like the Broadway show Hamilton and the work of the graffiti artist known as Banksy, and in older examples like the 1994 film Pulp Fiction-i.e., artists and works that not only win the approval of critics, aficionados, and general audiences alike, but do so quickly and in a way that seems to bring the two forms of recognition into harmony. Should works like these be considered anomalous cases, or do they point to a distinct social process at work? If it is the latter, then what are the dynamics of a cultural splash?

To shed light on these questions, this paper focuses on a single "pointy case" from the world of literature, or an extreme example capable of revealing mechanisms and relationships of wider sociological import (Small 2009; Pacewicz 2020). In the sections that follow, I present a case study of the production, diffusion, and reception of Infinite Jest, the sprawling American novel by David Foster Wallace, which became a runaway hit upon its publication in 1996. In the context of this discussion, what is noteworthy about Infinite Jest is the magnitude of the initial splash it created, which rested (as with the examples above) on its dual-cultural appeal and the "transcendent" qualities it seemed confer. As critics, fellow writers, and other literary tastemakers in the US heaped praise on the novel in the months surrounding its release, general audiences took note of the literary buzz and made it into an unexpected bestseller. Accordingly, Infinite Jest acquired both a halo of literary respectability and a measure of notoriety-the very ingredients that the "survival of reputation" literature would lead us to expect would give rise

\footnotetext{
2 The picture of transcendence as a slow, sedimentary process finds support in a range of empirical studies of artists and artworks. In a study of contemporary poets, for example, Dubois (2011, p. 87) shows that while it is common for a poet to achieve recognition from fellow poets by the age of 25 or 30 , "renown is obtained only at the end of a long path made up of compulsory stages," in which "the work begins to reach a wider audience" when the poet is "between 55 and 60." Interestingly, the chronology of this layering does not seem to matter: A work may be "consecrated" first by specialists—as in the case of One Hundred Years of Solitude-before diffusing to general audiences; or it may gain notoriety first on the basis of its entertainment value, its social or political import, or some other "nonartistic" quality before being "rediscovered" by specialists, sometimes decades later, and given the stamp of legitimacy. An example of the latter phenomenon is Harriet Beecher Stowe's 1852 anti-slavery novel Uncle Tom's Cabin, a book often cited as a classic of American literature today, but roundly dismissed in its own day for its maudlin tone, thin characterizations, clunky prose, and soap operatic plot. It was not until the mid-twentieth century that literary scholars, looking back on the book's role as a galvanizing symbol of the US abolition movement, reevaluated its worth and granted it the artistic credibility that had been withheld by their predecessors (Fluck 1992; Sundquist 1986; Tompkins 1981). On the corresponding phenomenon ("retrospective embedding") in film, see Allen and Lincoln (2004); on music, see Schmutz (2005).
} 
to an enduring appeal. For a time anyway, this prediction was upheld: It was common to see the novel described in superlative terms (such as "the ur-text of the literary [19]90s" [Temple 2018] and "unquestionably the novel of its generation" [Bissell 2016]) that seemed to lay the groundwork for its literary canonization. However, as I will elaborate below, a recent backlash has thrown Infinite Jest's long-term relevance into question. What accounts for this unusual pattern, and what lessons might it contain for sociologists concerned with the dynamics of cultural recognition?

My analysis is divided into two parts. Part one draws on two prominent theories of artistic practice-which I call the "art as a network-building activity" and the "art as an autonomous sphere" approaches-to build a retrospective account of how Infinite Jest became a blockbuster hit. Because the novel's experience places it outside of, or rather in between, the reach of the two theories, I argue that a synthesis is needed. Part one thus culminates in the argument that Infinite Jest became a hit not through the construction of a network (as the network-building approach would have it), nor through the ordinary dynamics of artistic consecration or commercial popularity (as the autonomous sphere approach would suggest), but through a third process that I call making a cultural splash. The key enabling factor in this process was the novel's presence in an intermediate "space between fields," which allowed it to gather samplings of recognition and renown and achieve a kind of "fast transcendence." Moving from the specific to the general, part two asks what the case study of Infinite Jest can teach us about the business of making a cultural splash. Here, I distill four potentially generalizable lessons from the novel's experience. The first of these centers on the suggestion that the competition to make a cultural splash is likely to favor works with conspicuously hybrid qualities. The second concerns the vital role played by cultural intermediaries in this process. The third involves the opportunities afforded by crisis or instability in an artistic field. Finally, the fourth point concerns the reputational instability that works in this category are likely to exhibit. Together, these lessons are meant to show that there is indeed a benefit to thinking about cultural splashes as, if not a discrete processual category, then a heuristic tool for illuminating the short-term dynamics of cultural recognition. In the conclusion, I will use this insight to reflect on the utility of transcendence as an analytic concept.

Data for this study come from two sources. The first is a collection of archival records from seven manuscript collections with materials related to Infinite Jest and its author. Totaling more than 4000 photographed pages, these materials include numerous drafts of the novel and related works; correspondence between the author and his agent, editors, mentors, and peers; and memoranda, promotional materials, sales reports, and other documents from the novel's publisher, Little, Brown \& Co. The second type of data is a collection of roughly 160 contemporaneously published book reviews, commentaries, and journalistic articles about Infinite Jest. Compiled from Nexis Uni, the articles come from sources that span the English-speaking world; the vast majority of these, however, are from the United States and Britain. (See the note on empirical sources for further details.) 


\section{How Infinite Jest became a literary sensation}

How did Infinite Jest become a rare example of an American literary blockbuster? The following account draws on two prominent theories of artistic practice, which I call the "art as a network-building activity" and the "art as an autonomous sphere" approaches, to address this question. Because the two approaches are sometimes held up as competing theories (see, e.g., Becker and Pessin 2006), I make use of a layered mode of exposition to show what each theory contributes to the larger whole and to clarify how they can be synthesized. Issues of clarity aside, there is another reason to underscore this separation: As we will see, the story of Infinite Jest's success falls "in between" the reach of the two theories. The need for both theories therefore supplies the first indication of what was unusual about the book's experience.

\section{Layer 1: The "art as a network-building activity" approach}

The first layer of this account comes from a family of sociological approaches that depict artistic achievements neither as straightforward "innovations" per se, nor as social constructions, but as performances rooted in networks that reach beyond the artist and the artwork to include actors, tools, and conditions that would normally be counted as "non-artistic." Broadly speaking, this is the premise of the "production of culture" approach (Peterson and Anand 2004), most notably Becker's (1982) Art Worlds, which describes the sociology of art's privileged unit of analysis as "network[s] of people" engaged in "cooperative activity, organized via their joint knowledge of conventional means of doing things." It is also the starting point for actor-network theory (ANT), an approach best known for its applications to science studies but used with growing frequency to analyze art and literature (Felski 2015). As I will elaborate below, ANT has been used in at least one instance to illuminate the career of David Foster Wallace (Hungerford 2016).

What does this approach suggest about the bases of Infinite Jest's success? The theory's first contribution comes from making a decisive break with the standard pop-journalistic account of the novel's reception, especially the widespread assumption that its success can be attributed simply to its "innovative" qualities or to the literary virtuosity of its author. In place of this assumption, the networkbuilding approach sets for itself the task of describing, in the fullest terms possible, the range of conditions, tools, and actors that were needed for the book to succeed. Not just the physical mechanics of this process, but also the hidden construction of meanings behind it require our attention. For example, what accounts for the intense reverence that seemed to attend any mention of Infinite Jest and its author in public discussions? As empirical grist for this discussion, consider the following vignettes about two seemingly unrelated aspects of Infinite Jest's production and reception - the first involving its unconventional use of endnotes, and second about the earliest published review of the book. 


\section{The endnotes}

One of Infinite Jest's most distinctive features is its 388 endnotes, which are spread across the book's final 96 pages. Literary scholars and critics have usually treated the endnotes as products of an expressly creative decision by the author and thus an unambiguously "literary" feature of the text. But how did the endnotes come about? Archival evidence shows that their origins can be traced to a series of surprisingly prosaic decisions involving the novel's cost and presentation. In a June 1992 "spec sheet" circulated soon after contracts for the book had been signed, Little, Brown \& Co. projected Infinite Jest's final length at 416 pages and its publication date as spring 1994. By June of the following year, however, it was clear that the project was both behind schedule and beyond its allotted word budget. By this point, Wallace's draft of the book had ballooned to over 400,000 words-or roughly 900 printed pages - with another 200,000 still on the way. Alarmed by the development, Wallace's editor Michael Pietsch wrote to warn the author that the book was becoming "way way too long" and that even with a highly compressed layout, a 600,000-word novel would require an abnormally high retail price, which would cripple sales. "So it is a good idea to try cutting now," Pietsch said. ${ }^{3}$

But Wallace had already advised his editor that he was constitutionally incapable of making cuts to his own writing. The task of managing Infinite Jest's length thus fell to Pietsch, who spent much of 1994 poring over multiple drafts of the book in search of excisable material and sending recommended edits to Wallace, most of which the author resisted. It was amid this standoff that Wallace suggested preserving the contested material in the form of endnotes, to be printed in what one reviewer called a "squinty six-point type" (Tortorello 1996). The solution stuck, although not because either party was happy with it. As late as October 1994, Pietsch was telling Wallace that, "It's unkind to ask readers to flip back and forth to the end of the book in order to read what you've written," even as the author was complaining to a mentor that Pietsch's edits had "fucked up a certain watertightness" in his draft. Yet, reviewers of the book, seeing none of these messy circumstances, treated the endnotes as a thematically significant feature of the book. The author, too, seemed to encourage this reading in promotional interviews, suggesting, for example, that the endnotes were there because "I wanted there to be this enormous amount of information, some of which meant something, some of which didn't" (Stivers 1996). ${ }^{4}$

\footnotetext{
3 "Specification Sheet (Information needed for Estimating Costs)," June 3, 1992. Little, Brown and Company Collection of David Foster Wallace 1987-2008. Harry Ransom Center. The University of Texas at Austin. Series I. Little, Brown files, 1987-2008, undated. Container 3.1; "Letter from Michael Pietsch to David Foster Wallace," June 10, 1993. Little, Brown and Company Collection of David Foster Wallace 1987-2008. Harry Ransom Center. The University of Texas at Austin. Series I. Little, Brown files, 1987-2008, undated. Container 3.2.

4 "Letter from Michael Pietsch to David Foster Wallace," October 21, 1994 and "Letter from Michael Pietsch to David Foster Wallace," November 30, 1994. Little, Brown and Company Collection of David Foster Wallace 1987-2008. Harry Ransom Center. The University of Texas at Austin. Series I. Little, Brown files, 1987-2008, undated. Container 3.2. "Letter from David Foster Wallace to David Markson," November 28, 1995. Steven Moore Collection of David Foster Wallace, 1987-2010. Harry Ransom Center. The University of Texas at Austin. Series I. Correspondence, 1987-2004, undated. Container 1.1.
} 


\section{The first published review}

The first published review of Infinite Jest was a November 1995 notice in the Review of Contemporary Fiction, a literary journal published by Dalkey Archive Press. Written by Steven Moore, the journal's editor, the review hailed Wallace's novel as "a vast, comic epic and a profound study of the postmodern condition" and compared the author favorably to Thomas Pynchon and William Gaddis, two luminaries of postmodern fiction. By some accounts, Moore's review set the tone for much of the critical reaction that followed.

Like the endnotes, however, the review's origins are not as straightforward as they appear. In the first place, the archival record shows that Moore was hardly a neutral arbiter of the book. Eight years prior, the critic had published Wallace's first nonfiction essay in his journal, and since then, the two had maintained a friendly correspondence. During that time, Moore had given Wallace feedback on an earlier draft of Infinite Jest (which he later described as "a mess") (Moore 2003), and Wallace had arranged for an early review copy to be sent to Moore. Upon receiving the book, the critic promptly wrote to Michael Pietsch to praise him for his editorial work on the project and to promise-even while acknowledging having read only "the first few hundred pages"- to "try to do justice to it in a review." "I know this is a risky and expensive venture for you and Little, Brown," Moore added, "so I hope for everyone's sake that it does well." Unsurprisingly, none of these points-about Moore's relationship with the author, his prior involvement with the project, or his consideration of the risks incurred by the press-were mentioned in the published review, which instead praised the novel in no uncertain terms ("so brilliant you need sunglasses to read it") and assigned credit for the achievement solely to Wallace (Moore 1995). ${ }^{5}$

What do these and other "behind the scenes" accounts of Infinite Jest's production and reception reveal about the book's success (see, e.g., Max 2012; Hungerford 2016)? At one level, they can be read simply as attempts to fill in some of the myriad gaps and silences left open by pop-journalistic and literary accounts. At another level, however, they point to a more provocative idea: namely, that the gaps and silences in question are not just random omissions, but vital ingredients in the book's reputation. From the standpoint of the network-building approach, these gaps and silences must be analyzed as part of the extensive boundary work needed to maintain the image of Infinite Jest as a "work of genius."

Take, for example, the seemingly banal question of the book's authorship: Although the archival record leaves no doubt as to Wallace's primary role in writing the text, it also shows that people like Michael Pietsch and Stephen Moore made indispensable contributions to the final product, not least by helping the author overcome his graphomania and disorganization. Recall, too, that it was Moore who, having helped Wallace rehabilitate his "messy" manuscript draft into a coherent

\footnotetext{
5 "Letter from Steven Moore to Michael Pietsch," October 30, 1995. Little, Brown and Company Collection of David Foster Wallace 1987-2008. Harry Ransom Center. The University of Texas at Austin. Series I. Little, Brown files, 1987-2008, undated. Container 3.1.
} 
text, then pivoted to the role of critic and began the work of reframing the book's remaining messiness as a literary virtue. Other critics, and later literary scholars, then followed suit by linking this feature of the book (which was neatly described in Moore's review as its "anticonfluential" form) to its fragmented narrative voice, its unconventional use of endnotes, and its themes of dislocation. Thus, what began as simple disorganization ultimately took on, through the contributions of various supporters, the appearance of a literary motif. To maintain the image of Wallace as the lone, virtuoso creative force behind it, a degree of boundary work was needed: Figures like Pietsch and Moore had to be relegated to one side of the conventional opposition between "author" and "support staff"; meanwhile, all the meaning-making work of critics had to be assigned to the realm of "interpretation," understood as distinct from the realm of "creation." "Finally, as the endnotes example illustrates, the role of emphatically "noncreative" factors such as timing, luck, and financial constraints had to be forgotten so that the novel could be grasped as a straightforwardly "creative" work, attributable solely to the magisterial vision of Wallace.

The great insight of the network-building approach, then, is to suggest that Infinite Jest's reputation was actually a complex and delicate achievement that rested on numerous secondary acts of framing, attribution, and "purification." To assimilate this point into our understanding, the approach suggests we think of Infinite Jest's success as a distributed phenomenon rather than an embodied one, or the product of a network, not the result of any specific feature of the book or its author. Thus, the theory's far-reaching conclusion is that Infinite Jest became a hit not, as nearly every pop-journalistic account would have it, through the virtuosic talents of one writer, but through the fabrication of a network - a concatenation of editors, literary agents, peers and mentors, reviewers, blurbers, and literary scholars, many of them working with the resources of publishing houses, literary journals, magazines, and newspapers to make the book a success.

As noted, this theory has the distinct benefit of clearing away many of the myths and assumptions that have long shaped the discussion about Infinite Jest. And yet for all its appeal, it also suffers from a major shortcoming that limits its ability to shed much further light on the situation. It is worth describing this problem in general terms first before turning to its effects here. The issue, as Gil Eyal (2013) puts it in a discussion of actor-network theory, is that the approach cannot offer a plausible account of how the interests of the parties to a network were formed and coordinated. To illustrate this point, Eyal cites Latour's (1988) famous depiction of the scientific "fact-builder" as a kind of a Machiavellian figure who "recruits" (read: manipulates) various allies into his service—allies who, for their part, begin to resemble passive dupes with no motives of their own. In ANT's rendering, Eyal (2013) says, rationality falls wholly "on the side of the Machiavellian actor, who

\footnotetext{
6 The point helps illustrate why ANT is the more fully realized of the two "art as a network-building activity" perspectives. In its explicit focus on production, the production of culture perspective leaves in place one of the key oppositions that ANT seeks to deconstruct: namely, between the production and consumption of meaning. From ANT's vantage point, a text's consumers are also potential co-producers of its meaning.
} 
translates (aligns, adjusts, interprets, shapes, distorts, misrepresents) the interests of all the allies, who themselves are either led, misled or resist."

Latour (1996, p. 373) has responded to this type of criticism by pointing out that ANT uses the term actor (and later, actant) in a broad way to refer to anything "that acts or to which activity is granted by others"- the point being that the theory sees nothing distinctive in human motives or interests per se. Whether or not this is a convincing defense in general, it seems to confirm Eyal's point that ANT is not especially useful for understanding people's interests or motivations. ${ }^{7}$ Indeed, we can see how this exchange would play out in relation to Hungerford's ANT-inspired study of David Foster Wallace, which depicts the author as a conniving figure-a kind of Machiavellian "art-builder"- and his supporters as lured into his service for mostly inexplicable reasons. It is to Hungerford's credit that her study takes the Machiavellian imagery to its logical endpoint. Framed around a provocative refusal to read Wallace's work, her account (“On Not Reading DFW") makes no bones about the fact that the author's aesthetic concerns fall outside of its purview. But one problem with this portrayal is that it is hard to square with the archival record, which shows a writer equipped with the normal range of human complexities-self-interested, yes, but also driven by a seemingly genuine love of art. Second, and more importantly, Hungerford's approach also leaves the study unable to account for a key proximate factor in Infinite Jest's success: not the author's motives, but those of the book's numerous "allies," most of whom seemed to gain nothing by supporting the book.

Why would so many critics, fellow writers, and others have rallied so energetically around the novel? For much of 1996, in fact, literary critics in the US seemed unusually eager to promote Infinite Jest. Because it is axiomatic in the sociology of literature that positive reviews and endorsements significantly shape a novel's sales and reputation (Childress 2017; Thompson 2010), any satisfying account must try to explain the basis of this support. Nor will it do simply to chalk it up to the savvy marketing campaign carried out by the book's publisher, Little, Brown \& Co. Although the press did promote Infinite Jest effectively-sending out cryptic postcards to magazines with phrases like INFINITE STYLE and INFINITE SUBSTANCE (Helmore 1996) — campaigns like this are not uncommon in the publishing world. The "hype" argument thus only pushes the burden of explanation to a new level: Why did so many reviewers and cultural commentators buy into the hype? Or, to put the question in Latourian terms, how were so many new "allies" recruited into Wallace's network? To answer these questions, we must turn to a theory better attuned to the dynamics of human interest and motivation, especially interests other than the straightforward pursuit of power and profit. This leads us to a second perspective on artistic practices: the "art as an autonomous sphere" approach. In the next section, I turn to the most fully realized example of this approach: Bourdieu's theory of fields, with its conception of social action as neither purely disinterested

\footnotetext{
7 Latour (1996, p. 373), for his part, seems to agree: "If a criticism can be levelled at AT it is, on the contrary, its complete indifference for providing a model of human competence. There is no model of (human) actor in AT nor any basic list of competences that have to be set at the beginning because the human, the self and the social actor of traditional social theory is not on its agenda."
} 
nor wholly calculated, but guided by people's subjective investments in the stakes of the "games" they play.

\section{Layer 2: Art as an autonomous sphere}

What would a field-based explanation of literary success look like, and what might it add to our understanding of Infinite Jest? How in particular would field theory explain the unusual convergence of support around the book in the months surrounding its release? It is worth noting from the outset that because Bourdieu describes the action taking place inside of fields as agonistic by default, the critical response to Infinite Jest in the US - indeed, anything resembling consensus in a field-is puzzling even from the standpoint of this approach. Puzzling, that is, but not inexplicable: Field theory does offer a prediction as to when the inhabitants of a field might be expected to set aside their normal disagreements and mobilize in pursuit of a common goal. Efforts like these, the theory says, are most likely to develop in the face of destabilizing shocks, especially shocks that threaten the field's integrity or the value of the "capital" at stake inside it. The key question, then, is whether the publication of Infinite Jest coincided with any such pressures.

In fact, even a cursory review of the major organs of literary debate in the US shows that Wallace's novel arrived on the scene in the midst of a perceived crisis of literary fiction. The immediate backdrop for this disruption was a profusion of commentary about the cultural effects of new media and communication technologies in the US. The growth of the internet had reached an inflection point in 1994, giving rise to a spate of 1995 books and articles about the dawning of the "digital age" (e.g., Negroponte 1995; Slouka 1995; Turkle 1995). However, variants of this discussion were taking place all over the world, in most cases without prompting fears about the death of literature (see, e.g., Lawson 1995; Shillingford 1995; Sommer 1995). Why, then, did the conversation take on such ominous tones in the US? In October of 1995, the literary scholar Elaine Showalter (1995), noting the recent flurry of "dire predictions of literary decline," asked this very question. She argued that the origins of this ferment could be traced to a strand of preexisting commentary about the fate of books and book-reading in American culture. In particular, Showalter argued, it was Alvin Kernan's The Death of Literature (1990) that had "set the agenda and the tone for our decade's apocalyptic musings" about literature. ${ }^{8}$ Other entries in this genre had soon followed (e.g., Bloom 1994; Postman 1992; Steiner 1996; Stephens 1991), culminating in the December 1994 publication of The Gutenberg Elegies: The Fate of Reading in An Electronic Age by the critic and essayist Sven Birkerts (for discussions of Birkerts, see Marchand 1995; Sharratt 1994; Stephenson 1995/96; Tolson 1995; Yardley 1994).

Birkerts' book offered a refinement of the general fears expressed by earlier writers. Not literature per se, Birkerts posited, but a particular kind of reading experience

\footnotetext{
${ }^{8}$ In a sociological study of "decline of literature" debates in the US, Ekelund (2002, p. 331) concurs with Showalter's view that the 1990s saw a "current" of discussion about literary "decline caused by large-scale technological changes."
} 
was facing extinction, and with it, a specific literary genre: the long, challenging, bravura novel associated with writers like Thomas Pynchon and John Barth. As the novelist Jonathan Franzen (1995) put it in a New Yorker essay, "[Birkerts] has in mind the broad-canvassed, big-audience novels of Tolstoy and Dickens, of Bellow and Steinbeck." Other writers added to this chorus about the negative effects of media transformations on literary culture. In a much-cited Harper's essay, Arthur Krystal (1996) argued that "novels [were] no longer news," and that works by "novelists and poets...no longer possesse[d] the cultural resonance" they once hadbecause "media [had] transformed the nature of existence by devaluing the idea of privacy." "If you look closely," wrote a Washington Post culture commentator in September 1995, "you can see the idea of serious fiction ebbing out of mass culture" (Streitfeld 1995; see also Coover 1993 and Nunberg 1997).

Infinite Jest thus arrived on an American literary scene awash in fears, both about the future of the long, challenging novel in particular and the "withering away of American literary fiction" in general (Yardley 1995). Notably, a cohort of selfdescribed "lobbyist[s] in the cause of literature" (Franzen 1995) had then emerged to respond to this crisis, some explicitly on the lookout for novels "to make sense of the new consciousness now being created by the emerging media" (Tolson 1995). Franzen (1995), for example, agreed with Birkerts that the long, bravura novel seemed to be "going the way of Shakespearean tragedy and Verdian opera." But he insisted that abstract pleas like Birkerts' would "not undo the damage." Instead, only new books relevant to "the daily life of the average American" could render the form "attractive and imperative" again (see also Sharratt 1994; Tolson 1995).

It is unsurprising that Infinite Jest soon became linked with this discussion. In the first place, the book's enormous length, labyrinthine plot, and so-called "demanding" qualities made it a natural prototype of the genre being mourned. The connection was then made explicit by several key participants in the "death of the novel" debate, including Franzen and Birkerts, who endorsed Infinite Jest in terms that echoed their earlier comments. Franzen's approval came in the form of a back-cover blurb that picked up where his New Yorker essay had left off: "Here is proof that the American novel can still engage with contemporary culture both broadly and deeply, can still run rings around the competing media, and can still attract the greatest talents of the day." Birkerts' support for Infinite Jest took the form of a 2000-word review in the Atlantic that praised the book for its savvy co-optation of new media forms. Rather than simply reassert old-fashioned literary principles, Birkerts (1996) argued, Wallace's novel "mimes, in its movements as well as in its dense loads of referential data, the distributed systems that are the new paradigm in communications. The book is not about electronic culture, but it has internalized some of the decentered energies that computer technologies have released into our midst."

Other reviewers and commentators, too, framed their responses to Infinite Jest in ways that were manifestly connected to the discussion about media transformations and the embattled state of US literary culture:

"[Wallace] is one of our best writers," critics will say-as if "our" writers were soon to square off against "their" writers in a battle royal before 10,000 rabidly jingoistic readers of quality fiction....[But] whether an "us" of 10,000 cur- 
rently exist to claim such a redoubtable talent as Wallace is the real question. (Tortorello 1996)

Of course, it's exhausting to read such a mega-book. This is the age of the sound bite. But...[Infinite Jest] teems with so much life and death, so much hilarity and pain, so much gusto in the face of despair that one cheers for the future of our literature. (Cryer 1996)

While reading William Gass's The Tunnel last year at this time, I feared I was witnessing the last of a dying breed, the encyclopedic American novel that began with Gaddis' Recognitions in 1955... [but] David Foster Wallace demonstrates that the encyclopedic novel is still alive and kickin' it. (Moore 1995)

In a world where politicians court MTV and pulp fiction rules, what market is there for a book that will take the average person 39 hours to read?... Somehow, however, sales have defied all expectations. (Kornblut 1996)

As Gerald Howard, Wallace's editor on two earlier projects, wrote in a private letter to his protégé Michael Pietsch: "I really never thought I would ever see this sort of book again-I thought they became extinct by the early seventies-but here it is, the grand overreaching masterpiece."9

The autonomous sphere approach thus adds a new layer to our understanding. By spotlighting the conditions of the US literary field at the time of Infinite Jest's publication, it offers a sense of why so many arbiters of literary taste would have been moved to rally around the book. In this way, it fills an important gap left open by the network-building perspective. Yet it is precisely at this point that the autonomous sphere approach runs up against a problem of its own. The problem springs from the challenge of linking Wallace and his novel analytically to any specific location in the field. Once again, the point is best explained by reference to Bourdieu's field theory: Across numerous studies of art and literature, Bourdieu (1993, 1996, 2017) depicts fields of cultural production as two-dimensional spaces, each structured by a vertical axis denoting the hierarchical ordering among the producers (as measured by the overall volume of their capital) and a horizontal axis denoting differences in the relative proportions of their capital. In artistic fields, those with the highest proportions of field-specific capital are said to occupy the autonomous region (or the sector marked by relative freedom from market constraint), while those with the lowest proportions occupy the heteronomous region (or the sector marked by relative subordination to the market).

The opposition between autonomy and heteronomy, Bourdieu says, is also imprinted on the subjectivities of artists, some of whom measure their success in terms of artistic honors, prizes, and so forth ("winner of the National Book Award"), and some of whom measure it in purely commercial terms ("New York Times bestselling author"). Of course, it is possible for an artist to pursue both kinds of success

\footnotetext{
9 "Letter from Gerald Howard to Michael Pietsch," February 7, 1996. Little, Brown and Company Collection of David Foster Wallace 1987-2008. Harry Ransom Center. The University of Texas at Austin. Series I. Little, Brown files, 1987-2008, undated. Container 3.1.
} 
at once-and most do- - but the theory holds that because artistic and commercial judgments obey antithetical logics, each form of success tends to be purchased at the cost of the other. Put differently, it is possible to accumulate artistic prestige and commercial rewards, and even to "balance" the two imperatives, but it should not be possible, per the logic of the theory, for either form of success to amplify the other. This prediction, it is worth noting, is ordinarily borne out in practice. ${ }^{10} \mathrm{But}$ in the case of Infinite Jest, it falls flat: Wallace's novel represents the odd case of a literary work whose commercial appeal not only did not undermine its ability to attract critical praise, but clearly enhanced it, and vice versa. For much of 1996, in fact, the two forms of recognition became fused in what one commentator described as a "self-perpetuating hype wave" (Stivers 1996), with the exuberant reviews sparking breathless media attention, which then prodded sales and generated further critical attention. As the novel began appearing on bestseller lists in February 1996, a stunned Michael Pietsch wrote to Wallace that the press had just "commissioned a fifth printing, another 5000, for 40,000 in print," leaving those at the press "nearly delirious." "Today David said no to going on the Today show," Pietsch wrote to a colleague. $^{11}$

In light of this situation, the question for the field theorist is simple: Where would we place Infinite Jest along the horizontal axis of Bourdieu's literary field, or the axis defined by the autonomy/heteronomy opposition? The answer is not obvious, and a close inspection of Wallace's creative strategy only deepens the mystery, albeit in a manner consistent with the story just told. In the years leading up to Infinite Jest's publication, the author made numerous pronouncements that seemed to link his profile to both sides of the literary field at once. In an essay called "Fictional Futures and the Conspicuously Young" (1988), for example, he issued a full-throated defense of literary autonomy that could not have been clearer if it had been written by Bourdieu himself: Decrying the profusion of "trash fiction," Wallace sounded the alarm about the supposed degradation of American literature and urged his fellow writers to take the duty of a literary calling seriously. Similarly, in a series of book reviews published from 1990 to 1992, he obsessed over the differences between a literary work's "importance" and its "quality."

"Position-takings" like these would seem to place Wallace in a location near the literary field's autonomous pole. Yet a very different picture emerges when we

\footnotetext{
$\overline{10 \text { So much so that we generally }}$ take for granted that "genre fiction" writers like Danielle Steele and John Grisham earn few awards, notwithstanding the skill needed to appeal to mass audiences, and that literary artists will sell fewer copies. Bourdieu's framework also helps make sense of specific episodes that might otherwise seem perplexing. For example, how else to explain the novelist Jonathan Franzen's awkward dealings with the Oprah Book Club in 2001, or the howls of protest that went up when Stephen King won a National Book Award in 2003? From the standpoint of Bourdieu's model, both episodes can be explained as attempts by writers situated in the autonomous region of the field to guard their literary capital against devaluation.

11 "Letter from Michael Pietsch to David Foster Wallace," February 22, 1996; "Letter from Michael Pietsch to David Foster Wallace," April 18, 1996; and "Letter from Michael Pietsch to Gerald Howard," February 15, 1996. Little, Brown and Company Collection of David Foster Wallace 1987-2008. Harry Ransom Center. The University of Texas at Austin. Series I. Little, Brown files, 1987-2008, undated. Containers 3.1 and 2.7.
} 
consider his diagnosis of the problem with 1990s American fiction and the "cure" he prescribed. In the author's view, US literature's chief failing was its growing insularity and disconnectedness from the lives and experiences of ordinary people. Too often, he argued, writers succumbed to "the avant-garde pitfall," or "the idea that you're writing for other writers, so you don't worry about making yourself accessible or relevant. You worry about making it structurally and technically cutting edge: involuted in the right ways, making the appropriate intertextual references, making it look smart. Not really caring about whether you're communicating with a reader" (Miller 1996). Consequently, Wallace argued, avant-garde fiction had become "divorced from the real concerns...of living" (quoted in Kennedy and Polk 1993) and "hellaciously unfun to read" (quoted in Caro 1996). This disconnection, meanwhile, had been amplified by changes outside the world of literature:

The world that I live in consists of 250 advertisements a day and any number of unbelievably entertaining options, most of which are subsidized by corporations that want to sell me things. The whole way that the world acts on my nerve endings is bound up with stuff that the guys with leather patches on their elbows would consider pop or trivial or ephemeral. (Miller 1996)

In Wallace's view, the solution to this problem was to eschew self-conscious literary artistry, not by acceding to consumer demand per se, but by operating a strategy that closely resembled it. In multiple interviews, he argued that the best way to "engage a reader...whose sensibility has been formed by pop culture" (quoted in Miller 1996) was to make use of "the strategies that regular entertainment uses" (quoted in Donahue 1996; my emphasis). "I use a fair amount of pop stuff in my fiction," he explained. "It's just the texture of the world I live in" (Miller 1996).

Wallace had, in fact, made the first steps in this direction years earlier, in the 1989 story collection Girl with Curious Hair, which included short stories about popculture phenomena like the TV shows Late Night with David Letterman and Jeopardy!, along with a 140-page novella about the making of a fictional McDonald's TV commercial. With Infinite Jest, he took the strategy a step further by folding the concern with pop entertainment recursively into the book's form: In the action of the book, the phrase "Infinite Jest" refers to the title of an underground movie said to be so blissfully entertaining as to put its viewers into a state of deadly paralysis. The joke, then, was that the novel Infinite Jest shared a dubious affinity with the mindless entertainment it parodied. ${ }^{12}$ Put differently, the author aimed not just to comment on the late-twentieth century experience of being entranced by popular media, but to simulate it by mimicking the glut of stimuli emanating from a society "obsessed with entertainment and self-gratification" (Kakutani 1996).

Expressed in field-theoretical terms, the problem is that whatever artistic motives lay behind Infinite Jest, a key aspect of the book's profile was determined by Wallace's strict obedience to the dictates of popular judgment, taste, and expression-or essentially what Bourdieu calls heteronomy. By his own account, Wallace had tried

\footnotetext{
12 This suggestion was even clearer in the book's working title: Infinite Jest: A Failed Entertainment. However, Pietsch nixed this subtitle out of fear that it would invite mockery from reviewers.
} 
to "create something that would feel the way the culture would feel," so that "the entertainingness of the book, and the entertainingness of the stuff that the book talks about, enter into a kind of intercourse" (Stivers 1996). As the author put it in a different interview, the goal was to create a layered work that would offer "some of the richness and challenge and emotional and intellectual difficulty of avant-garde literary stuff...but to do that in such a way that it's also pleasurable" (quoted in Miller 1996). But how would we capture both sides of this dual stance in terms of what Bourdieu would call a single "position-taking" in the field?

One way to deal with this problem would be to split the difference between autonomy and heteronomy by assigning Wallace a middle position along the field's horizontal axis. But this is no solution, in fact, since it fails to capture the essence of his strategy, which was less about "balancing" autonomy and heteronomy than about staking out a position of extreme autonomy through an arch approximation of extreme heteronomy. A second approach, then, would be to say that because Infinite Jest's heteronomous qualities were merely ironic, the novel "really" belonged to the field's autonomous pole. But this is no solution either, since it flies in the face of Bourdieu's own dictum that no product or practice is inherently artistic or commercial (or political, economic, religious, etc.), but only becomes so relationally, or through the effects it generates in the field. If Infinite Jest's effects were demonstrably bound up with its "pop" characteristics, then those features cannot be written off as somehow "less real" than the others.

A third possibility would be to describe Infinite Jest in terms of a strategy of "playing both sides" of the literary field at once, as Pouly (2016) does of the Zadie Smith's novel White Teeth in her Bourdieu-inspired study of "literary bestsellers." Doubtless this is the most promising of the three solutions, in that it captures the "twofold truth" at the heart of Infinite Jest's existence. Yet it too runs up against a basic precept of field theory, which is Bourdieu's (1989, p. 16) insistence that field and social space are objectivist concepts, or tools for representing the full "ensemble of...relations" in which a set of "agents, groups [and] institutions" are embedded (see also Bourdieu 1975). Throughout his work, Bourdieu makes clear that agents are tied, via their socially relevant properties, to determinate positions in social space. It is not that these properties somehow "place" their bearers within an already existing topography, furthermore, but the other way around: Social space itself is "constructed [so] that the closer the agents... [are] within this space, the more common properties they have; and the more distant, the fewer" (Bourdieu 1989, p. 16). To say that Wallace occupied two positions at once, then, would be to concede that he did not constitute a determinate reference point for locating other agents and goods in the literary field.

All of this is to suggest that Infinite Jest cannot be assigned-nor can its success be attributed - solely to the workings of a literary field, or to any other autonomous sphere. Stated in general terms, the problem is that the autonomous sphere approach is not well equipped to deal with hybrid cases, meaning, in the case of literature, works that seem to belong both "inside" and "outside" of the literary field at once. In fact, of the two approaches considered here, it is the network-building approach, with its focus on how alliances are struck across conventional institutional boundaries, that is better suited to this task. It seems clear, then, that any satisfying account of Infinite Jest's 
success must incorporate insights from both theories. How can the two approaches be combined?

\section{Synthesis: Infinite Jest in the space between fields}

My synthesis of the two perspectives draws on Gil Eyal's (2013) theory of the "spaces between fields," which effects a rapprochement between field theory and actor-network theory. Briefly stated, Eyal's argument is that while Bourdieu's and Latour's theories are in one sense incompatible, they are also oriented to different (indeed, "symmetrical") problems: Whereas the field concept is meant to overcome the false dichotomy between descriptions of social action as either "interested" or "disinterested," the actor-network concept is meant to overcome the false opposition between the post hoc language of innovation and the trivializing language of social construction. This means that a working peace can be established between the two theories by assigning each its own "jurisdiction": namely, "fields to Bourdieu, and the spaces between them to Latour" (Eyal 2013, p. 164). Concretely, the point is that the tools of field theory can be called upon to address questions about the coordination of motives and interests, while the tools of ANT can be invoked to address questions about how a domain of social action comes to be differentiated from others in substantive terms (i.e., how a given practice comes to be seen as "scientific," "artistic," "political," or "economic").

Applying this synthesis to Infinite Jest leads to a novel description of the book's path to cultural acclaim. In keeping with the network approach, it holds that the book's success rested on the assembly of a network that reached beyond literary circles into other institutional realms. In keeping with the autonomous sphere approach, it stipulates that what set this network-building process in motion was not the machinations of a crafty "art-builder," but a collection of literary specialists acting in sublimated defense of their artform. But in keeping with neither theory, the synthesis suggests that much of the social action behind Infinite Jest's success took place in an intermediate zone (or in what Eyal calls the "thick volume of the boundary") between the literary field and the domains of popular media, culture, and entertainment. Put differently, Infinite Jest was not an exclusive phenomenon of any field or network, but a product of the "space between fields." Accordingly, the mechanics of its success were not reducible to the ordinary dynamics of artistic consecration or commercial success. But neither were they wholly unique. Instead, I have suggested that we can think of the book's success in terms of a process specific to interstitial spaces. This is the process I call making a cultural splash. In the next section, I will develop this idea further by identifying some potentially general features of this phenomenon.

\section{"Fast Transcendence," or the forms and dynamics of a cultural splash}

One way to clarify the idea of a cultural splash is to draw out the double-sided relationship between the present example and the notion of transcendence as described in the introduction. In one sense, the story of Infinite Jest's success reaffirms the core insight of transcendence, since it shows that the combination of general and specific 
recognition-indeed, even small samplings of the two ${ }^{13}$ - can give an expressive work an enchanted quality. It was Max Weber ([1916] 1958), of course, who used the term disenchantment to describe the loss of meaning and coherence that results from the fragmentation of the modern world into competing "value-spheres" (art, science, politics, religion, the market, domestic life, and so forth). Disenchantment in this context thus refers to a lost sense of unity-in Weber's case, the unity of a past in which the answers to life's big questions could be tied together into a coherent whole. In a sociology of expressive works, by extension, enchantment would refer to the ability to recover a sense of unity in the face of fragmentation, especially by linking the categories of "rarified art" and "pop culture." Meanwhile, the effect we should expect an enchanted work to produce is something like the quasi-religious devotion described in the opening lines of a 2015 Newsweek article about Wallace's legacy:

Read what follows with a stern caveat emptor in mind, for it has been written by an unabashed David Foster Wallace fanboy, one of those forlorn, bespectacled young men covertly handed a copy of Infinite Jest in his formative years, and who subsequently recited passages from the novel the way early Christians, hiding in dim catacombs, must have read with secret, feverish ecstasy from the epistles of Paul. You know the kind: mop-haired hipsters dragging themselves through The Broom of the System, Wallace's first novel, getting their angry fix from the essays of A Supposedly Fun Thing I'll Never Do Again and Consider the Lobster. I was one of them. I am one of them still. (Nazaryan 2015)

The case of Infinite Jest thus upholds the basic insight behind the transcendence concept. But even as it affirms this idea, it also complicates the picture sketched in the introduction. After all, rather than establish a blending of recognition and renown in the ordinary way-i.e., slowly, through a multi-staged layering process involving a gradual appropriation by general audiences or an accidental "rediscovery" by critics - the novel did so quickly, becoming an immediate crossover hit. The notion of a cultural splash is meant to spotlight this peculiar temporal element.

To reconcile these two points, I suggest we think of a cultural splash as a kind of "fast transcendence," or an effect generated by expressive works that manage to unmoor themselves, however temporarily, from the limiting effects of being classified as "art" or "pop." As I have suggested, this shortcut process seems to be a phenomenon of the "spaces between fields," specifically the interstitial zone between the domains of art or high culture and commercial culture. Let me extend this point by drawing out four additional lessons from the preceding case study.

\footnotetext{
13 As I will elaborate below, while the early critical praise heaped on the book constituted a form of artistic consecration, it came up short by a more conventional measure of artistic prestige: namely, awards. By the same token, while sales of the book were impressive for a work of literary fiction, it is worth remembering that the 82,500 copies it sold during the 1990 s did not place it among the 100 topselling American novels of that decade (Publishers Weekly 2017). Thus, we must conclude that while Infinite Jest attracted doses of literary and popular recognition, it did not attract either type of acclaim in especially great abundance.
} 


\section{Hybrid characteristics}

The first and most straightforward is that the competition to make a cultural splash is likely to favor expressive works with conspicuous hybrid characteristics, especially works that comingle themes, styles, or techniques from the worlds of art and commercial entertainment. Not just Infinite Jest, but all of the examples mentioned in this paper fit this description: They are works that made names for themselves by "speaking twice" through layered performances, either as artworks with pop-cultural affinities (e.g., Hamilton) or as popular entertainments that gesture toward the world of art (e.g., Pulp Fiction). ${ }^{14}$

It is worth pausing here to defend the specific claim that Infinite Jest's hybridity, or its neither-here-nor-there status with respect to the art/commerce divide, was the key to its appeal. Up to this point, I have discussed this feature of the book only as it relates to the problem of classifying it for analytic purposes. But it is crucial to recognize that the same classification problem also became an explicit focus of public discussion surrounding the novel. Most reviewers, in fact, highlighted Infinite Jest's hybridity in one form or another, with a few going so far as to describe it as an actual "problem" for the task of criticism. One critic, for example, argued that its "brilliant amalgamation of high and low culture" had created "a frustrating critical problem" for reviewers: "Wallace...seems to have preemptively booby-trapped the novel to undermine the pretensions of literary criticism" (Haggar 1996). Another was so troubled by the paradox at the heart of the book-that it could be read either as popular entertainment or as a condemnation of the same- that she sought out the author personally to ask whether he was secretly scorning his readers. Having heard back, the critic then reported: "my fear that the book was personally mocking and threatening me, the faithful reader, was, well, paranoid and off-base. Wallace does not consider his book the same kind of media entertainment that he is critiquing. It should have been obvious" (Stivers 1996).

But whether they presented it as a stumbling block for criticism or a straightforward asset, US critics and commentators consistently gravitated to the book's categorical blurriness as the marker of its significance. Many, for example, put forward versions of the point that the book had "bridge[d] the gap between avant-garde fiction... and commercial escapism" (Caro 1996), making it both "a great read and a literary feat" (Haggar 1996). One reviewer argued that the novel had successfully "alchemize[d]...identifiable pop culture references into precious gold" (Strom 1996). Others highlighted its discordant mix of genre elements, such as its blending of traditional literary qualities with "goofy humor" and "aspects of a nightmarish sci-fi novel" (Cryer 1996) or its unusual amalgamation of "mystery, squalor, paranormal intrigue, tooth-extracting dysthymia, and quality potty humor" (Tortorello

\footnotetext{
14 Unsurprisingly, all of these works have at one time or another been labeled or mislabeled postmodern. It is worth noting, though, that while the blending of discordant elements can be done playfully and/or nihilistically, as the term postmodern would suggest, it can also be done soberly, moralistically, ideologically, or in the service of some modern project. Hybridity need not go hand in hand with a postmodern sensibility. (Hence Infinite Jest has sometimes been called metamodern [see, e.g., Abramson 2015]).
} 
1996). Still other critics made the same point through studied comparisons between the book and incongruous groupings of other authors and texts:

[Wallace is] equally adept at the Pynchonesque epic and the Nicolson Bakeresque minute....It's Thomas Wolfe without Maxwell Perkins, done in the hallucinogenic style of Terry Gilliam and Ralph Steadman. (Kakutani 1996)

The overall effect is something like a sleek [Kurt] Vonnegut chassis wrapped in layers of post-millennial [Émile] Zola....[Wallace's] facility with weird science equals that of popular peer Mark Leyner.... One can even detect reflections of Philip K. Dick. (McInerney 1996)

Infinite Jest is...surreal in the Douglas Adams or the Don DeLillo manner. (Fellman 1996)

Wallace is to literature what Robin Williams or perhaps Jim Carrey is to live comedy. (Bruni 1996)

Wallace can play it high or low, a sort of Beavis-and-Egghead approach that should spell cult following at the nation's brainier colleges. (Sheppard 1996)

A jacket blurb calls it 'a Naked Lunch for the '90s (lots of drugs); but it's also a Gravity's Rainbow (epic preposterousness) and a Lolita (salted clues, interlinked motifs), with white-knuckle suspense and gross-out violence right out of Stephen King. (Gates 1996)

The common thread among these responses, put simply, was that one should pay attention to Infinite Jest because of its hybrid characteristics.

But if the splash Infinite Jest made was closely bound up with its hybridity, this quality alone was not sufficient to make the book a success. Many expressive works are hybrid in some sense-and hybridity itself is a slippery analytic notion. ${ }^{15}$ If anything, the case study may be taken to show that even works that are crafted expressly to span the art/commerce divide need favorable surrounding conditions to make a cultural splash.

\section{The vital role of cultural intermediaries}

The second lesson is that cultural splashes would seem to be more common in settings saturated with cultural intermediaries, particularly intermediaries who specialize in the tasks of "selling" art, "consecrating" commerce, and effecting "dialogue" between the two worlds (Bourdieu 1984; Nixon and du Gay 2002; Maguire and Matthews 2014). The reason is straightforward: The more numerous and internally

\footnotetext{
15 To offer a trivial example: The influence of French colonialism once made Vietnamese food a "hybrid" cuisine - for a time, that is, until café au lait became Vietnamese coffee, crêpes became ban $x e o$, and baguette sandwiches became banh mi, which is to say, until all the hybrids were "purified" and subsumed into the category of Vietnamese. The point being that hybridity is not an objective feature of a cultural object, but a function of the boundary-making activity taking place around it.
} 
differentiated the intermediaries are, the more likely they are to generate meta-cultural discourse (i.e., expression about expressive works) capable of disrupting the normal antinomy between art and commerce.

In the case of Infinite Jest, it was a varied collection of cultural intermediaries-literary gatekeepers, media and cultural commentators, and rank-and-file book reviewers-who were responsible for the "self-perpetuating hype wave" that propelled the book's success (Stivers 1996). But what exactly were the dynamics of this hype? It is important to recognize, first, that the fanfare created by the intermediaries did not arise from, nor did it reflect, any unanimous love for the book. More than a few reviewers and commentators, in fact, expressed serious misgivings about the novel's merits. Crucially, however, even the naysayers tended to speak of Infinite Jest in highly portentous terms that reinforced the sense that its publication was a major literary event. Why would this be? The model developed here, centered on the image of an intermediate space between fields, provides an answer: namely, that the book, by virtue of its position in social space, drew two subsets of cultural intermediaries into a recursive, mutually referential exchange. As arbiters of literary taste praised the novel (albeit largely because of its "pop" potential), and, vice versa, as chroniclers of pop culture gave it a degree of notoriety (albeit largely because of the literary buzz around it), a feedback loop was set in motion, such that the recognition conferred by each group amplified the other. As the response reached a crescendo, even the novel's detractors felt compelled to cite, without endorsing, the reactions of others. An illustrative example of this "second-order hype" can be found in the opening lines of the negative review published in the New York Daily News: "It's in a bookstore near you right now. You'll know it when you see it. It weighs 3.3 pounds. It runs 1079 pages. It has 388 endnotes. And it may, or may not, be The Great American Novel. We think not. But everyone else thinks so" (Connelly 1996).

\section{Crisis or instability in an artistic field}

Infinite Jest was the beneficiary of fortuitous timing, its publication having coincided with a campaign by literary specialists to rescue the long, challenging novel from extinction. Based on this observation, a third - and somewhat counterintuitive-lesson from the preceding case study is that an expressive work stands a better chance of making a cultural splash if the artistic field from which it originates is in crisis, or if the artform it "stands for" faces extinction. In such cases, incumbents in the field (i.e., those with an interest in the artform's or genre's survival) may be predisposed to rally around the work as part of a wider campaign on behalf of the field.

Once again, this dynamic favors works that manage to situate themselves in an intermediate space between fields. In the case of Infinite Jest, it was the book's dual profile as a literary and commercial work that made it useful to literary tastemakers as a tool for "renegotiating" the boundary of the literary field. By praising the novel as a literary achievement, they could absorb into the category of "literary fiction" a work with pop characteristics and thereby expand the field's jurisdiction. The generalizable point is that moments of crisis may provide opportunities to make a 
cultural splash because they render general popularity and commercial success more palatable to cultural specialists. Put differently, if critics and aficionados have the luxury of judging works according to field-specific criteria during "settled times," the arrival of "unsettled times" demands a new approach. Crises may compel them to abandon their exclusive tastes and find the merit in works that seem capable of expanding the field's audience or broadening its reach.

\section{Reputational instability}

The fourth and final lesson is indicated by a relatively sudden-some would say unexpected-decline in Infinite Jest's reputation. After decades of being treated with reverence and awe in US public discussion, the novel has lately been the target of intense backlash. Recast by its detractors as an overrated work and even an emblem of white male privilege, the book's long-term literary eminence now stands in question (see, e.g., Fischer 2015; Garber 2018; Rhode 2018; Taranto 2018). What does this development suggest about the business of making a cultural splash? One plausible answer, of course, is that it says nothing at all-that it is a purely idiosyncratic feature of Infinite Jest's experience. But I find this answer to be unconvincing. In the first place, the recent backlash is only the latest expression of the novel's longstanding tendency to elicit wildly different responses, even in apparently similar contexts. Furthermore, this propensity is demonstrably bound up with the conditions of the book's initial reception. In my view, then, the lesson is that if making a cultural splash means leading a charmed existence in the short run, it may also entail greater-than-usual reputational instability in the long run.

Two early illustrations of Infinite Jest's reputational instability are worth noting here. The first comes from the novel's failure to win any major literary awards despite the high expectations many observers had for it in the months after its publication. Here, for example, was how one of Infinite Jest's earliest champions, the writer Walter Kirn (1996), opened his review:

Next year's book awards have been decided. The plaques and citations can now be put in escrow. With Infinite Jest, by David Foster Wallace...the competition has been obliterated. It's as though Paul Bunyan had joined the NFL or Wittgenstein had gone on 'Jeopardy!' The novel is that colossally disruptive. And that spectacularly good.

But when the awards in question were distributed, Infinite Jest came away emptyhanded. In a letter to Stephen Moore, Wallace himself expressed disappointment at the result: "IJ didn't even get nominated for a Nat. B. Aw. [National Book Award], so it seems like my 15 minutes are over and things are back to normal." ${ }^{16}$ But while the result may have been surprising to some literary insiders, it is consistent with the

\footnotetext{
16 "Letter from David Foster Wallace to Steven Moore," October 8, 1996. Stephen Moore Collection of David Foster Wallace, 1987-2010. Harry Ransom Center. The University of Texas at Austin. Series I. Correspondence, 1987-2004, undated. Container 1.3.
} 
model developed here. Its main point, after all, is that Infinite Jest's appeal did not rest on any unanimous belief in the book's artistic merits, or indeed on its presence at any location within the literary field. Instead, it was the book's status as a boundary object-its presence at the field's margins, and its utility as a tool for striking alliances, erecting boundaries, and so forth — that held the key to its success (Star 1988, 2010; Star and Griesemer 1989).

A second illustration of Infinite Jest's reputational instability comes from the deeply mixed - in fact, mostly negative-critical response to the book in the English-speaking world outside of the US. On the surface, there is nothing surprising in this response. One of the most well-established findings in the sociology of culture, in fact, is that a text may lend itself to divergent, even contradictory, readings when introduced into multiple settings (DeVault 1990; Griswold 1987). What is surprising, however, is that in many cases, critics from outside the US reached their verdicts based on readings that were substantively congruent with those of US critics. A comparison between the American and British reviews of Infinite Jest illustrates this pattern. At one level, the two sets of reviews are virtually interchangeable: They contain uniform descriptions of the novel's key themes and stylistic features, parallel accounts of its relationship with other literary works, and even concurring assessments of its strengths and weaknesses. Their framings aside, both sets of reviews depict Infinite Jest as an inventive, sometimes brilliant book that is nonetheless hampered by its own extravagances. As the model developed in this paper would suggest, we can explain this congruence using the language of fields, as the product of a homology of vision and judgment among the reviewers-a homology rooted in the numerous analogs, ties, and affinities between the US and British literary fields.

But if Infinite Jest had been an exclusive phenomenon of the literary field, we would expect reviewers' interpretations to have dictated the "uses" to which they put it. If anything, though, the opposite was true: In both settings, it was the book's status as a boundary object between fields that determined its utility. Thus, to explain why reviewers reached opposite verdicts on Infinite Jest, we must shift to the language of networks. This approach highlights the fact that the book's profile in the US was shaped by a sudden demand for novels capable of moving the frontier of literary fiction in the direction of commercial fiction. In Britain, by contrast, there was no felicitous match between the novel and its surrounding environment. Hence, British critics depicted Infinite Jest as an object lesson in the power of hype. Tellingly, even British reviewers used the novel to perform a type of boundary work-but in Britain, its conspicuous Americanness made it handy for reaffirming the national boundary between the British and American traditions. Accordingly, British reviewers wrote blasé notices that wasted no chance to make dismissive remarks about American literature: "Is it any good?," asked one critic. "Well, pretty good, is the short answer. However, I doubt it's the work of genius that some American critics have hailed it as" (Williams 1996). Another review called Infinite Jest the latest in a series of "groaning Yankee imports" that had "been acclaimed by various transatlantic pundits as, if not a work of genius, then something very like it" (Private Eye 1996). In truth, the reviewer wrote, it was "none of these things, just the usual halfway reasonable idea spun out to about five times its natural length, and attended by maximal American kookiness." 


\section{Conclusion}

In this paper, I have focused on an exemplary case of an expressive work that attracted widespread cultural attention — and even seemed to achieve iconic statusnot through the ordinary dynamics of artistic consecration or commercial popularity, but through a separate process that I have referred to as making a cultural splash. As part one showed, the novel Infinite Jest became a hit in the US through a peculiar process that brought together elements of the network-building and consecration processes described in other studies. Owing partly to the fortuitous timing of its publication, the book attracted the attention of literary specialists, who championed it as part of an effort to modify and adjust the boundary of the US literary field. Their campaign then set in motion a feedback loop in which literary acclaim fed the book's notoriety, while notoriety fed more acclaim. Moving from the specific to the general, I sought in part two to draw out some broader lessons from the case study. Works that attract attention by making a cultural splash, I argued, are likely to exhibit hybrid characteristics; to flourish in settings that are saturated by cultural intermediaries; to benefit from crisis or instability in an artistic field; and to exhibit greater-than-usual reputational instability.

One way to summarize the main contribution of this study is by linking it to the "survival of reputation" literature discussed in the introduction. The great insight of that literature lay in the suggestion that the most successful expressive works set themselves apart through the composition, not the overall volume, of the recognition they receive. On this view, for example, the reason the Mona Lisa is an iconic painting is not that it occupies a preeminent place in the eyes of art historians (which it does not-when asked to name a "great painting," art historians are far more likely to cite lesser-known works ${ }^{17}$ ), nor because of its commercial popularity (by which measure the work of a kitsch artist like Thomas Kincaide might rank higher). Instead, the key to its appeal is its ability to be, as one writer has put it, both "a classic of Western art and pop, hip, and cool" at once (Sassoon 2001a; see also Sassoon $2001 b$ ). But if the great insight of the "survival of reputation" literature was that recognition and renown can combine synergistically, its deficiency was to anchor this idea imprecisely to the dimension of time and to the question of a work's staying power. There was always a potential tautology in this suggestion: A work endures because it develops a crossover appeal, but crossover appeals themselves typically require time to develop (thus implying a work with preexisting staying power).

\footnotetext{
17 A 2014 poll of art "luminaries" yielded the following list of candidates for the title of "greatest painting in the world": Black Suprematic Square by Kazimir Malevich; Abstract Painting No. 3 by Ad Reinhardt; Young Lady in 1866 by Édouard Manet; Nine Dragons by Chen Rong; Dort or Dordrecht: The Dort Packet-Boat from Rotterdam Becalmed by J. M. W. Turner; Saturn Devouring His Son by Francisco de Goya; the Isenheim Altarpiece by Matthias Grünewald; and Da Vinci’s Mona Lisa (Thomas 2014). In keeping with Bourdieu's model, then, artistic specialists show a clear tendency to cite less popular works. It is telling, furthermore, that the one respondent who listed the Mona Lisa felt the need to issue the following defensive explanation: "If we define greatness as having exercised the greatest hold over cultural imaginations across the world, there is only one answer. I'm sorry to trigger a collective groan."
} 
The notion of transcendence resolves this tautology by decoupling Lang and Lang's insight from the question of a work's endurance. What it suggests is that the blending of recognition and renown provides not staying power but an enchanted aura that attaches to a work and protects it from limiting associations. This paper takes this decoupling a step further by showing that the aura of transcendence can develop quickly and that it need not confer staying power. What becomes of expressive works that effect this "fast transcendence"? Although no general pattern can be derived from a single case, Infinite Jest offers a suggestive model. It shows that works that make a cultural splash are not bound, like fads and fashions, to see their appeal fade over time; but neither are they guaranteed a place alongside classics of their genres.

\section{Note on empirical sources}

The archival records used for this study come from the following manuscript collections, all of which are housed at the Harry Ransom Center at the University of Texas, Austin:

Bonnie Nadell Collection of David Foster Wallace, 1980-2008.

David Foster Wallace Papers, 1971-2008.

Don DeLillo Papers, circa 1959-2003.

Little, Brown and Company. Collection of David Foster Wallace, 1987-2008.

McSweeney's (Firm). Records, circa 1930s-2013 (bulk 2000-2012).

Steven Moore Collection of David Foster Wallace, 1987-2010.

T. Coraghessan Boyle. Papers, 1887-2012 (bulk 1970-2010).

Acknowledgements This research was supported by the Society of Hellman Fellows program at the University of California, San Diego. The author would like to thank Pat Fox, Danning Xie Medvetz, Seth Merritt, Josh Roiland, Alvaro Santana-Acuña, Philip Smith, the anonymous AJCS reviewers, and the staff at UT-Austin's Harry Ransom Center for their advice and assistance.

Open Access This article is licensed under a Creative Commons Attribution 4.0 International License, which permits use, sharing, adaptation, distribution and reproduction in any medium or format, as long as you give appropriate credit to the original author(s) and the source, provide a link to the Creative Commons licence, and indicate if changes were made. The images or other third party material in this article are included in the article's Creative Commons licence, unless indicated otherwise in a credit line to the material. If material is not included in the article's Creative Commons licence and your intended use is not permitted by statutory regulation or exceeds the permitted use, you will need to obtain permission directly from the copyright holder. To view a copy of this licence, visit http://creativecommons.org/licen ses/by/4.0/.

\section{References}

Abramson, S. 2015. Metamodernism 101: How David Foster Wallace Started a Cultural Revolution. Medium [online]. Available at: https://medium.com/just-words/metamodernism-101-8cdb8563e0 (Accessed 13 July 2021). 
Allen, M.P., and A.E. Lincoln. 2004. Critical Discourse and the Cultural Consecration of American Films. Social Forces 82: 871-894.

Askin, N., and M. Mauskapf. 2017. What Makes Popular Culture Popular? Product Features and Optimal Differentiation in Music. American Sociological Review 82 (5): 910-944.

Becker, H. 1982. Art Worlds. Berkeley: University of California Press.

Becker, H.S., and A. Pessin. 2006. A Dialogue on the Ideas of 'World' and 'Field.' Sociological Forum 21 (2): 275-286.

Benzecry, C. 2011. The Opera Fanatic: Ethnography of an Obsession. Chicago: University of Chicago Press.

Bielby, W.T., and D.D. Bielby. 1994. All Hits Are Flukes: Institutionalized Decision Making and the Rhetoric of Network Prime-Time Program Development. American Journal of Sociology 99 (5): 1287-1313.

Birkerts, S. 1994. The Gutenberg Elegies: The Fate of Reading in An Electronic Age. New York: Faber and Faber.

Birkerts, S. 1996. The Alchemist's Retort: A Multi-Layered Postmodern Saga of Damnation and Salvation. The Atlantic. February.

Bissell, T. 2016. Everything About Everything: David Foster Wallace's 'Infinite Jest' at 20. New York Times. 1 February [online]. https://www.nytimes.com/2016/02/07/books/review/everything-abouteverything-david-foster-wallaces-infinite-jest-at-20.html. Accessed 30 July 2020.

Bloom, H. 1994. The Western Canon: The Books and School of the Ages. New York: Harcourt.

Bourdieu, P. 1975. The Specificity of the Scientific Field and the Social Conditions of the Progress of Reason. Social Science Information 14 (6): 19-47.

Bourdieu, P. 1980. The Production of Belief: Contribution to an Economy of Symbolic Goods. Media Culture \& Society 2 (3): 261-293. https://doi.org/10.1177/016344378000200305.

Bourdieu, P. 1984. Distinction: A Social Critique of the Judgment of Taste. Cambridge: Harvard University Press.

Bourdieu, P. 1989. Social Space and Symbolic Power. Sociological Theory 7 (1): 14-25. https://doi.org/ $10.2307 / 202060$.

Bourdieu, P. 1993. The Field of Cultural Production. New York: Columbia University Press.

Bourdieu, P. 1996. The Rules of Art: Genesis and Structure of the Literary Field. Stanford: Stanford University Press.

Bourdieu, P. 2017. Manet: A Symbolic Revolution. London: Polity.

Bowker, G.C., and S.L. Star. 1999. Sorting Things Out: Classification and Its Consequences. Cambridge: MIT Press.

Bruni, F. 1996. The Grunge American Novel. New York Times Magazine. 24 March.

Caro, M. 1996. The Next Big Thing: Can a Downstate Author Withstand the Sensation Over His 1,079Page Novel? Chicago Tribune. 23 February.

Childress, C.C. 2017. Under the Cover: The Creation, Production, and Reception of a Novel. Princeton: Princeton University Press.

Childress, C.C., and N.E. Friedkin. 2012. Cultural Reception and Production: The Social Construction of Meaning in Book Clubs. American Sociological Review 77 (1): 45-68.

Connelly, S. 1996. The Great American Novelty. New York Daily News. 14 February: 36.

Coover, R. 1993. Hyperfiction: And Hypertext Is Only the Beginning. Watch Out! New York Times. 29 August.

Cryer, D. 1996. Review of Infinite Jest by David Foster Wallace. Newsday. 12 February.

DeVault, M.L. 1990. Novel Readings: The Social Organization of Interpretation. American Journal of Sociology 95 (4): 887-921.

Donahue, A.M. 1996. Infinite Text: Tennis, 12-step, and Terrorism, In a Big Book of Life and Laughs. The Boston Phoenix. 21-28 March.

Dubois, S. 2011. Joining the Literary Pantheon: How Contemporary French Poets Attain Renown. Revue Française De Sociologie 52 (5): 87-115.

Ekelund, B.G. 2002. 'The Age of Criticism': Debating the Decline of Literature in the US, 1940-2000. Poetics 30: 327-340.

Eyal, G. 2013. Spaces Between Fields. In Bourdieu and Historical Analysis, ed. P. Gorski, 158-182. Durham: Duke University Press.

Fellman, R. 1996. Jest Joking: Infinite Jest Infinitely Impresses. The College Hill Independent. 11 April.

Felski, R. 2015. The Limits of Critique. Chicago: University of Chicago Press. 
Fischer, M. 2015. David Foster Wallace, Beloved Author of Bros. Slate. 13 August [online]. https://slate. com/culture/2015/08/men-who-love-david-foster-wallace-what-s-wrong-with-bros-obsessing-overinfinite-jest.html. Accessed 13 July 2021.

Fluck, W. 1992. The Power and Failure of Representation in Harriet Beecher Stowe's Uncle Tom's Cabin. New Literary History 23 (2): 319-338.

Franzen, J. 1995. The Reader in Exile. The New Yorker. 6 March: 119-123.

Garber, M. 2018. David Foster Wallace and the Dangerous Romance of Male Genius. The Atlantic. 9 May [online]. https://www.theatlantic.com/entertainment/archive/2018/05/the-world-still-spinsaround-male-genius/559925/. Accessed 13 July 2021.

Gates, D. 1996. Levity's Rainbow. Newsweek. 12 February: 80.

Griswold, W. 1987. The Fabrication of Meaning: Literary Interpretation in the United States, Great Britain, and the West Indies. American Journal of Sociology 92 (5): 1077-1117.

Haggar, D. 1996. It's Showtime! At the Apocalypse: The Media and the Culture of Addiction in David Foster Wallace's Infinite Jest. Harvard Advocate. Fall.

Hallett, T., O. Stapleton, and M. Sauder. 2019. Public Ideas: Their Varieties and Careers. American Sociological Review 84 (3): 545-576.

Helmore, E. 1996. Knocking Them Dead with Pleasure; A 33-Year-Old Illinois Prodigy in a Bandanna is America's Newest Literary Sensation. The Independent (London). 24 February: 8.

Hirsch, E.D., Jr. 1987. Cultural Literacy: What Every American Needs to Know. Boston: Houghton Mifflin.

Hungerford, A. 2016. On Not Reading DFW. In Making Literature Now, 141-167. Stanford: Stanford University Press.

Kakutani, M. 1996. A Country Dying of Laughter. In 1,079 Pages. New York Times. 13 February: C17.

Kennedy, H., and G. Polk. 1993. Looking for a Garde of Which to be Avant: An Interview with David Foster Wallace. Whiskey Island Magazine. Spring.

Kernan, A. 1990. The Death of Literature. New Haven: Yale University Press.

Kirn, W. 1996. Long Hot Novel. New York Magazine. 12 February.

Kornblut, A.E. 1996. A Literary Heavyweight: You May Not Be Able to Put 'Infinite Jest' Down. Assuming You Can Pick It Up. New York Daily News. 13 February.

Krystal, A. 1996. Closing the Books. Harper's Magazine. March.

Lang, G.E., and K. Lang. 1988. Recognition and Renown: The Survival of Artistic Reputation. American Journal of Sociology 94: 79-109.

Lang, G.E., and K. Lang. 1990. Etched in Memory: The Building and Survival of Artistic Reputation. Chapel Hill: University of North Carolina.

Latour, B. 1988. Science in Action: How to Follow Scientists and Engineers through Society. Cambridge: Harvard University Press.

Latour, B. 1996. On Actor-Network Theory: A Few Clarifications. Soziale Welt 47 (4): 369-381.

Lawson, M. 1995. Will our children read books? Is European culture doomed? Will all the arts reach us via a screen? The Independent (London). 9 April: 18.

Luhmann, N. 2000. Art as a Social System. (trans: E.M. Knodt) Stanford: Stanford University Press.

Maguire, J.S., and J. Matthews, eds. 2014. The Cultural Intermediaries Reader. Thousand Oaks: Sage Publications.

Mallard, G. 2005. Interpreters of the Literary Canon and Their Technical Instruments: The Case of Balzac Criticism. American Sociological Review 70: 992-1010.

Marchand, P. 1995. Review of The Gutenberg Elegies: The Fate of Reading in An Electronic Age, by Sven Birkerts. Toronto Star. 28 January: J17.

Max, D.T. 2012. Every Love Story Is a Ghost Story: A Life of David Foster Wallace. New York: Penguin.

McDonnell, T.E., C. Bail, and I. Tavory. 2017. A Theory of Resonance. Sociological Theory 35 (1): $1-14$.

McInerney, J. 1996. The Year of the Whopper. New York Times Book Review. 6 March.

Miller, L. David Foster Wallace: The Salon Interview. Salon. 9-22 March.

Moore, S. 1995. Review of Infinite Jest by David Foster Wallace. Review of Contemporary Fiction: $135-136$.

Moore, S. 2003. The First Draft Version of Infinite Jest. Howling Fantods [online]. http://www.theho wlingfantods.com/ij_first.htm. Accessed 30 July 2020. 
Nazaryan, A. 2015. The Turbulent Genius of David Foster Wallace. Newsweek. 8 January [online]. https://www.newsweek.com/2015/01/16/turbulent-genius-david-foster-wallace-297688.html. Accessed 9 Sept 2021.

Negroponte, N. 1995. Being Digital. New York: Alfred A. Knopf.

Nixon, S., and P.D. Gay. 2002. Who Needs Cultural Intermediaries? Cultural Studies 16 (4): 495-500.

Nunberg, G., ed. 1997. The Future of the Book. Berkeley: University of California Press.

Pacewicz, J. 2020. What Can You Do with a Single Case? How to Think About Ethnographic Case Selection Like a Historical Sociologist. Sociological Methods and Research. https://doi.org/10.1177/ 0049124119901213.

Peterson, R.A., and N. Anand. 2004. The Production of Culture Perspective. Annual Review of Sociology 30: 311-334.

Peterson, R.A., and R.M. Kern. 1996. Changing Highbrow Taste: From Snob to Omnivore. American Sociological Review 61: 900-907.

Postman, N. 1992. Technopoly: The Surrender of Culture to Technology. New York: Knopf.

Pouly, M.P. 2016. Playing Both Sides of the Field: The Anatomy of a 'Quality' Bestseller. Poetics 59: 20-34.

Private Eye (UK). 1996. The Novel in a Fix. Issue 902: 12 July.

Publishers Weekly. 2017. Publishers Weekly Annual Adult Bestsellers 1990-2013. 30 June [online]. https://www.publishersweekly.com/pw/by-topic/industry-news/bookselling/article/74149-publi shers-weekly-annual-adult-bestsellers-1990-2013.html. Accessed 30 July 2020.

Rhode, J. 2018. Why Insufferable People Love Infinite Jest. Paste. 29 June [online]. https://www.paste magazine.com/books/david-foster-wallace/why-insufferable-people-love-infinite-jest/. Accessed 13 July 2021.

Santana-Acuña, A. 2014. How a Literary Work Becomes a Classic: The Case of One Hundred Years of Solitude. American Journal of Cultural Sociology 2 (1): 97-149.

Santana-Acuña, A. 2020. Ascent to Glory: How One Hundred Years of Solitude Was Written and Became a Global Classic. New York: Columbia University Press.

Sassoon, D. 2001a. Why I Think Mona Lisa Became an Icon. Times Higher Education. 21 September [online]. https://www.timeshighereducation.com/news/why-i-think-mona-lisa-became-an-icon/ 164983.article. Accessed 9 Sept 2021.

Sassoon, D. 2001b. Mona Lisa: The History of the World's Most Famous Painting. New York: HarperCollins.

Schiffrin, A. 2001. The Business of Books. New York: Verso.

Schmutz, V. 2005. Retrospective Cultural Consecration in Popular Music: Rolling Stone's Greatest Albums of All Time. American Behavioral Scientist 48 (11): 1510-1523.

Schudson, M. 1989. How Culture Works: Perspectives from Media Studies on the Efficacy of Symbols. Theory and Society 18 (2): 153-180.

Sharratt, B. 1994. Are There Books in Our Future? New York Times. 18 December.

Sheppard, R.Z. 1996. Mad Maximalism. Time. 19 February.

Shillingford, J. 1995. On-line books boost industry. The Age (Melbourne, Australia). 26 September.

Showalter, E. 1995. Apocalypse Not. The Guardian. 27 October.

Slouka, M. 1995. War of The Worlds: Cyberspace and The High-tech Assault on Reality. New York: Basic Books.

Small, M.L. 2009. How Many Cases Do I Need?' On Science and the Logic of Case Selection in Fieldbased Research. Ethnography 10 (1): 5-38.

Smith, T. 2007. Narrative Boundaries and the Dynamics of Ethnic Conflict and Conciliation. Poetics 35 (1): $22-46$.

Sommer, A.K. 1995. People of the Book. The Jerusalem Post. 28 July.

Squires, C. 2009. Marketing Literature: The Making of Contemporary Writing in Britain. London: Palgrave Macmillan.

Star, S.L. 1988. The Structure of Ill-Structured Solutions: Boundary Objects and Heterogeneous Distributed Problem Solving. In Readings in Distributed Artificial Intelligence, ed. M. Huhns and L. Gasser. Kaufman: Menlo Park.

Star, S.L. 2010. This is Not a Boundary Object: Reflections on the Origin of a Concept. Science Technology and Human Values 35 (5): 601-617.

Star, S.L., and J. Griesemer. 1989. Ecology, "Translations" and Boundary Objects: Amateurs and Professionals in Berkeley's Museum of Vertebrate Zoology, 1907-39. Social Studies of Science 19 (3): 387-420. 
Steiner, G. 1996. No Passion Spent: Essays 1978-1996. New York: Faber and Faber.

Stephens, M. 1991. The Death of Reading: Will a Nation That Stops Reading Eventually Stop Thinking? Los Angeles Times Magazine. 22 September.

Stivers, V. 1996. The Jester Holds Court: A Conversation with David Foster Wallace. Stim. 5 May.

Streitfeld, D. 1995. Book Report. The Washington Post. 10 September.

Stephenson, W. 1995/96. The Message Is the Medium: A Reply to Sven Birkerts and The Gutenberg Elegies. Chicago Review 41(4), 116.

Strom, E. 1996. Review of Infinite Jest. Bookpage. February.

Sundquist, E.J., ed. 1986. New Essays on Uncle Tom's Cabin. Cambridge: Cambridge University Press.

Taranto, J. 2018. On Outgrowing David Foster Wallace. Los Angeles Review of Books. 15 September [online]. https://lareviewofbooks.org/article/on-outgrowing-david-foster-wallace/. Accessed 13 July 2021.

Temple, E. 2018. A Century of Reading: The 10 Books That Defined the 1990s. LitHub. 26 October [online]. https://lithub.com/a-century-of-reading-the-10-books-that-defined-the-1990s/. Accessed 30 July 2020.

Thomas, K.D. 2014. The Greatest Painting in the World: 10 Luminaries Cast Their Ballots. ArtNEWS. 26 November [online]. https://www.artnews.com/feature/greatest-painting-world-10-luminaries-castballots-3168/. Accessed 13 July 2021.

Thompson, J.B. 2010. Merchants of Culture. Cambridge: Polity Press.

Tolson, J. 1995. Review of The Gutenberg Elegies: The Fate of Reading in An Electronic Age by Sven Birkerts. The New Republic. 22 May.

Tompkins, J. 1981. Sentimental Power: Uncle Tom's Cabin and the Politics of Literary History. Glyph 8: 79-102.

Tortorello, M. 1996. Review of Infinite Jest by David Foster Wallace. Hungry Mind Review.

Turkle, S. 1995. Life on the Screen: Identity in the Age of the Internet. New York: Simon and Schuster.

Uzzi, B., and J. Spiro. 2005. Collaboration and Creativity: The Small World Problem. American Journal of Sociology 111 (2): 447-504.

Verboord, M. 2011. Market Logic and Cultural Consecration in French, German and American Bestseller Lists, 1970-2007. Poetics 39: 290-315.

Wallace, D.F. 1988. Fictional Futures and the Conspicuously Young. Review of Contemporary Fiction 8 (3): 36-53.

Weber, M. [1916] 1958. Religious Rejections of the World and Their Directions. In From Max Weber, eds. H. H. Gerth and C. Wright Mills, 323-359. New York: Oxford University Press.

Williams, J. 1996. The Joke's on Us as David Foster Wallace Hits Big with His Weighty New Novel. GQ (UK). August.

Yardley, J. 1994. Closing the Book on Books. Washington Post. 11 December: X3.

Yardley, J. 1995. Review of The Liars' Club: A Memoir by Mary Karr. Washington Post. 18 June.

Publisher's Note Springer Nature remains neutral with regard to jurisdictional claims in published maps and institutional affiliations.

Thomas Medvetz is an Associate Professor of Sociology at the University of California, San Diego. He has made it through Infinite Jest once (in three attempts). 